\title{
Perception of Caesarean Section among Pregnant Women in a Rural Missionary Hospital
}

\author{
P. O. Ezeonu' ${ }^{1}$, K. C. Ekwedigwe1, M. E. Isikhuemen ${ }^{2 *}$, M. O. Eliboh ${ }^{3}$, R. C. Onoh ${ }^{1}$, L. O. Lawani', \\ L. O. Ajah'1, E. I. Dimejesi' \\ ${ }^{1}$ Department of Obstetrics and Gynecology, Federal Teaching Hospital, Abakaliki, Nigeria \\ ${ }^{2}$ Department of Obstetrics and Gynaecology, University of Benin Teaching Hospital, Benin City, Edo State, Nigeria \\ ${ }^{3}$ National Obstetric Fistula Centre, Abakaliki, Nigeria \\ Email: maradona4real2002@yahoo.com
}

How to cite this paper: Ezeonu, P.O., Ekwedigwe, K.C., Isikhuemen, M.E., Eliboh, M.O., Onoh, R.C., Lawani, L.O., Ajah, L.O. and Dimejesi, E.I. (2017) Perception of Caesarean Section among Pregnant Women in a Rural Missionary Hospital. Advances in Reproductive Sciences, 5, 33-38. https://doi.org/10.4236/arsci.2017.53004

Received: July 18, 2017

Accepted: August 19, 2017

Published: August 22, 2017

Copyright $\odot 2017$ by authors and Scientific Research Publishing Inc. This work is licensed under the Creative Commons Attribution International License (CC BY 4.0).

http://creativecommons.org/licenses/by/4.0/

\begin{abstract}
Introduction: Caesarean section is the delivery of a foetus through an incision made on the uterus. It is useful in situations where vaginal delivery is not feasible. Women in our setting usually see it as a reproductive failure and a sign of weakness. Our aim was to evaluate the perception of caesarean section among pregnant women attending antenatal clinic in a rural missionary hospital. Methodology: This was a cross-sectional study conducted at Mile 4 missionary hospital, Abakaliki among women attending routine antenatal clinic. Information was obtained from respondents with the aid of a questionnaire. Ethical clearance was obtained for the study. Data was analysed using the Statistical Package for Social Sciences (SPSS) version 21. Results: A total of 209 pregnant women participated in this study. Their age ranged from 14 to 43 with a mean age of $27 \pm 5$ years. One hundred and seventy two women $(82.3 \%)$ have heard of caesarean section in the past. Eighteen $(8.6 \%)$ have had caesarean section in the past while 5 were not willing to undergo the procedure again. Sixty (28.7\%) are not willing to undergo caesarean section even when it is indicated. Conclusion: Despite awareness of caesarean section, women do not appear to have a positive attitude towards the procedure.
\end{abstract}

\section{Keywords}

Perception, Caesarean Section, Rural Hospital

\section{Introduction}

Caesarean section is an alternative for women whom vaginal delivery is not feasible. It involves the delivery of a baby through an incision made on the uterus af- 
ter the age of viability [1] [2]. Its indications may be maternal or foetal. It is a relatively safe surgical procedure though may be associated with complications. In developed countries the incidence of caesarean section is on the increase unlike developing nations [3].

Women in less developed countries often think that caesarean section signifies reproductive failure. It is usually bad news for them when told that they will be delivered through caesarean section. For those that will eventually give their consent, it is done with so much unnecessary delay. This little time between counselling and giving consent for caesarean section may be important in clinical practice for conditions such as foetal distress and antepartum haemorrhage that require emergency caesarean section. With a positive perception of caesarean section, it is expected that the decision-delivery interval will be reduced.

Previous studies have shown the perception of caesarean section in various settings. The results showed that women are not favourably disposed to caesarean section but will accept it if the life of the mother and/or foetus are in danger [4] [5] [6].

The aim of this study was to determine the perception of caesarean section among pregnant women attending antenatal clinic in a rural missionary hospital.

\section{Materials and Method}

\subsection{Setting}

This study was conducted in Mile 4 missionary hospital, Abakaliki, Ebonyi State. The facility provides care for children and pregnant mothers at a subsidized rate. It serves the less privileged in that environment.

\subsection{Subjects}

This consisted of women who attended antenatal clinic between June 1 and July 1, 2017. Convenient sampling method was used to select the respondents for the study. Participants were assured of confidentiality at all times. Pregnant women who have attended at least one antenatal clinic were involved in the study. Those who refused to give consent were excluded from the study. Refusal of any woman to participate in the study did not influence her management in any way.

\subsection{Study Design}

This was a cross sectional descriptive study. The sample size was calculated from the formula $\mathrm{n}=\mathrm{z}^{2} \mathrm{pq} / \mathrm{d}^{2}$ where $\mathrm{z}$ is the normal standard deviation set at 1.96, confidence level specified at 95\%, the tolerable error margin (d) at 5\%, $(q=1.0$ $\mathrm{P}$ ) and $\mathrm{P}$ was $12.3 \%$ based on the prevalence from a previous study done in a Teaching Hospital (Abakaliki, Nigeria) [4]. Minimum sample size was calculated to be 166 .

\subsection{Research Instrument}

A questionnaire was used to obtain sociodemographic variables, information on 
awareness of caesarean section, complications of caesarean section and attitude of respondents towards caesarean section. The questionnaire was administered by the interviewers.

\subsection{Ethical Consideration}

Ethical Clearance was obtained from the Ethical Committee of Mile 4 hospital, Abakaliki, Nigeria.

\subsection{Data Analysis}

Data was analysed using the Statistical Package for Social Sciences (SPSS) version 21 .

\section{Results}

A total of 209 pregnant women participated in this study. Their age ranged from 14 to 43 with a mean age of $27 \pm 5$ years. The mean parity was $2 \pm 2$. The average gestational age was 28 weeks. A good proportion of respondents were between the ages of 25 and 29 (41.6\%). The sociodemographic variables are shown in Table 1 .

One hundred and seventy two women (82.3\%) have heard of caesarean section in the past while $37(17.7 \%)$ have not heard of it. Eighteen $(8.6 \%)$ have had caesarean section in the past while 5 were not willing to undergo the procedure again. Out of those that had caesarean section, one experienced rejection by spouse after delivery. Majority of women (66.5\%) believed that their husbands were the ones to give consent for caesarean section. (Table 2)

About half of the study participants (47.4\%) said it was mandatory to inform their pastors before a caesarean section. Sixty $(28.7 \%)$ are not willing to undergo caesarean section even when it is indicated. Only 7 (3.3\%) attributed refusal of caesarean section to the complications of the procedure.

\section{Discussion}

In this study, the participants were between the ages of 16 and 43 years. The mean age of the study population was 27 years. This is not surprising as it is within the reproductive age group. Women in this age group have a better fertility profile. This is quite similar to a previous study conducted in southwest Nigeria and another conducted in a teaching hospital located in the urban part of the state where this study was conducted [4] [5].

A hundred and seventy two $(82.3 \%)$ of the study population have heard of caesarean section in the past. In a related study conducted in Northwest Nigeria, a high proportion of respondents were aware of caesarean section [6]. Those who were not aware of caesarean section were mainly those who had just come for antenatal registration and those who were not regular with their routine antenatal clinic. It is important to educate women on the different modes of deliv- 
Table 1. Sociodemographic variables.

\begin{tabular}{|c|c|}
\hline Variable & Frequency (\%) \\
\hline \multicolumn{2}{|l|}{ Age } \\
\hline$<15$ & $1(0.5)$ \\
\hline $15-19$ & $5(2.4)$ \\
\hline $20-24$ & $57(27.3)$ \\
\hline $25-29$ & $87(41.6)$ \\
\hline $30-34$ & $40(19.1)$ \\
\hline $35-39$ & $17(8.1)$ \\
\hline $40-44$ & $2(1)$ \\
\hline \multicolumn{2}{|l|}{ Occupation } \\
\hline Trading & $67(32.1)$ \\
\hline Farming & $57(27.3)$ \\
\hline Housewives & $41(19.6)$ \\
\hline Students & $30(14.4)$ \\
\hline Artisan & $14(6.7)$ \\
\hline \multicolumn{2}{|l|}{ Level of Education } \\
\hline Primary & $16(7.7)$ \\
\hline Secondary & $110(52.6)$ \\
\hline Tertiary & $78(37.3)$ \\
\hline No Formal Education & $5(2.4)$ \\
\hline \multicolumn{2}{|l|}{ Marital Status } \\
\hline Single & $11(5.3)$ \\
\hline Married & $197(94.3)$ \\
\hline Divorced & $1(0.5)$ \\
\hline \multicolumn{2}{|l|}{ Parity } \\
\hline Nullipara (No Previous Childbirth) & $71(34)$ \\
\hline Primipara (1 Previous Childbirth) & $41(19.6)$ \\
\hline Multipara & $82(39.2)$ \\
\hline Grandmultipara & $15(7.2)$ \\
\hline
\end{tabular}

Table 2. Perception of who to give consent for caesarean section.

\begin{tabular}{cc}
\hline Who gives consent & Frequency (\%) \\
\hline The woman & $41(19.6)$ \\
Husband & $139(66.5)$ \\
Other relatives & $2(1)$ \\
I don't know & $27(12.9)$ \\
\hline
\end{tabular}


ery during the antenatal period so that caesarean section will not be entirely strange to them when indicated during the period of labour. This may shorten the time interval between when a decision is taken to do caesarean section and when women give their consent.

Sixty women (28.7\%) were not willing to undergo caesarean section. Only a few of these attributed this to the complications associated with the procedure while the majority did not give any reason for their negative attitude towards caesarean section. In a study conducted in southwest Nigeria, majority (94.2\%) preferred vaginal delivery [5]. A related study done in the urban region of the state where this study was conducted showed that $13.4 \%$ of respondents were not favourably disposed to caesarean section. In that study, the fear of death was the major reason women refused caesarean section but this was not the situation in this study.

In this study, 18 (8.6\%) have had caesarean section in the past for various indications. Out of this, 5 are not willing to undergo a repeat caesarean section. The reasons given for this were the complications that followed the procedure and the discriminatory attitudes of others towards them. In a related study, $10 \%$ of the respondents have had caesarean section in the past while $23 \%$ of them were not favourably received at home [4]. In a study done in Enugu, Nigeria, $7.22 \%$ of respondents have had caesarean section in the past [7]. It is important for people to be well informed about caesarean delivery and change their negative attitude towards it. This may increase the acceptability of caesarean section among pregnant women when it is indicated. In a study done in Benin, Nigeria only $6.1 \%$ of pregnant women were willing to accept caesarean section as a method of delivery [8]. In a study conducted in Nigeria, some of the respondents had a negative opinion towards caesarean section because they believed it was punishment for marital infidelity and for the interest of the doctor while some believed it was the devils work [9]. The refusal of caesarean section has been associated with poor maternal and perinatal outcomes [10].

A good number of women (66.5\%) believe their husbands should be the one to give consent for caesarean section. This is not entirely surprising in this setting as the majority of decisions are often left for the men who are believed to be the head of the family. There is sometimes delay in decision making with regards to maternal health when the husbands of these women are not available. This contributes to maternal mortality. Women should have the right to decide what will happen to them including the decision to have a caesarean section performed on them.

This study is limited by its sample size. It is a hospital based study hence its results cannot be generalised.

\section{Conclusion}

Awareness of caesarean section appeared high in this study, but this did not translate into acceptability for the procedure. A good number of women in this study 
believe that their husbands should be the ones to give consent for caesarean section. The community does not appear to have a positive attitude towards caesarean section.

\section{References}

[1] Kwawukume, E.Y. and Emuveyan, E.E. (2002) Comprehensive Obstetrics in the Tropics. Ashante and Hittscher, Damsona, 321-329.

[2] Jaiyesimi, R.A. and Ojo, O.E. (2003) Caesarean Section. In: Okonufua, E.F. and Kunle, O., Eds., Contemporary Obstetrics and Gynecology for Developing Countries, Women's Health and Action Research Centre of Nigeria, Benin City, 592-619.

[3] Grivell, R.M. and Dodd, J.M. (2011) Short- and Long-Term Outcomes after Cesarean Section. Expert Review of Obstetrics \& Gynecology, 6, 205-215.

https://doi.org/10.1586/eog.11.5

[4] Adeoye-Sunday, I. and Kalu, C.A. (2011) Pregnant Nigerian Women's View of Caesarean Section. Nigerian Journal of Clinical Practice, 14, 276-279.

https://doi.org/10.4103/1119-3077.86766

[5] Owonikoko, K.M., Akinola, S., Adeniji, O.A. and Bankole, A.O. (2015) Women's Perception and Experience of Caesarean Delivery in Ogbomoso, Southwest Nigeria. Journal of Pregnancy and Child Health, 2, 161. https://doi.org/10.4172/2376-127X.1000161

[6] Ashimi, A.O., Amole, T.G. and Aliyu, L.D. (2013) Knowledge and Attitude of Pregnant Women to Caesarean Section in a Semi-Urban Community in Southwest Nigeria. Journal of the West African College of Surgeons, 3, 46-61.

[7] Gunn, J.K.L., Ehiri, J.E., Jacobs, E.T., Ernst, K.C., Pettygrove, S., Center, K.E., et al. (2017) Prevalence of Caesarean Sections in Enugu, Southeast Nigeria: Analysis of the Data from the Healthy Beginning Initiative. PLoS ONE, 12, e0174369. https://doi.org/10.1371/journal.pone.0174369

[8] Aziken, M., Omo-Aghoja, L. and Okonofua, F. (2007) Perceptions and Attitudes of Pregnant Women towards Caesarean Section in Urban Nigeria. Acta Obstetricia et Gynecologica Scandinavica, 86, 42-47. https://doi.org/10.1080/00016340600994950

[9] Orgi, E.O., Ogunniyi, S.O. and Onwudiegwu, U. (2003) Beliefs and Perception of Pregnant Women at Ilesa about Caesarean Section. Tropical Journal of Obstetrics and Gynaecology, 20, 141-143.

[10] Chigbu, C. and Iloabachie, G. (2007) The Burden of Caesarean Section Refusal in a Developing Country Setting. British Journal of Obstetrics and Gynaecology, 114, 1261-1265. https://doi.org/10.1111/j.1471-0528.2007.01440.x 
Submit or recommend next manuscript to SCIRP and we will provide best service for you:

Accepting pre-submission inquiries through Email, Facebook, LinkedIn, Twitter, etc. A wide selection of journals (inclusive of 9 subjects, more than 200 journals)

Providing 24-hour high-quality service

User-friendly online submission system

Fair and swift peer-review system

Efficient typesetting and proofreading procedure

Display of the result of downloads and visits, as well as the number of cited articles Maximum dissemination of your research work

Submit your manuscript at: http://papersubmission.scirp.org/

Or contact arsci@scirp.org 